OPEN ACCESS

Edited by:

Christian Roger Marc Hermans, Université Libre de Bruxelles, Belgium

Reviewed by:

Amitava Rakshit,

Banaras Hindu University, India Jianting Zhu,

University of Wyoming, United States

Shankar Lal Jat,

Indian Council of Agricultural

Research (ICAR), India

*Correspondence:

Bo Zhang

zhangbo@ms.xjb.ac.cn

Fanjiang Zeng

zengfj@ms.xjb.ac.cn

Specialty section:

This article was submitted to

Plant Nutrition,

a section of the journal

Frontiers in Plant Science

Received: 07 February 2021

Accepted: 06 May 2021

Published: 07 June 2021

Citation:

Zhang $B$, Tang $G$, Yin $H$, Zhao $S$, Shareef $M$, Liu B, Gao $X$ and Zeng $F$ (2021) Groundwater Depths Affect

Phosphorus and Potassium Resorption but Not Their Utilization in a Desert Phreatophyte in Its Hyper-Arid Environment.

Front. Plant Sci. 12:665168. doi: 10.3389/fpls.2021.665168

\section{Groundwater Depths Affect Phosphorus and Potassium Resorption but Not Their Utilization in a Desert Phreatophyte in Its Hyper-Arid Environment}

\author{
Bo Zhang 1,2,3*, Gangliang Tang1,3, Hui Yin 1,3, Shenglong Zhao ${ }^{4}$, Muhammad Shareef ${ }^{1,3}$, \\ Bo Liu ${ }^{5}$, Xiaopeng $\mathrm{Gao}^{6}$ and Fanjiang Zeng ${ }^{1,3,7 *}$
}

\begin{abstract}
'Xinjiang Key Laboratory of Desert Plant Roots Ecology and Vegetation Restoration, Xinjiang Institute of Ecology and Geography, Chinese Academy of Sciences, Urumqi, China, ${ }^{2}$ National Engineering Technology Research Center for Desert-Oasis Ecological Construction, Xinjiang Institute of Ecology and Geography, Chinese Academy of Sciences, Urumqi, China, ${ }^{3}$ Cele National Station of Observation and Research for Desert-Grassland Ecosystems, Cele, Xinjiang, China, ${ }^{4}$ Northwest Institute of Eco-Environment and Resources, Academy of Science, Lanzhou, China, ${ }^{5}$ College of Resources and Environment, Linyi University, Linyi, China, ${ }^{6}$ Department of Soil Science, University of Manitoba, Winnipeg, MB, Canada, ${ }^{7}$ State Key Laboratory of Desert and Oasis Ecology, Xinjiang Institute of Ecology and Geography, Chinese Academy of Sciences, Urumqi, China
\end{abstract}

Nutrients are vital for plant subsistence and growth in nutrient-poor and arid ecosystems. The deep roots of phreatophytic plants are necessary to access groundwater, which is the major source of nutrients for phreatophytes in an arid desert ecosystem. However, the mechanisms through which changes in groundwater depth affect nutrient cycles of phreatophytic plants are still poorly understood. This study was performed to reveal the adaptive strategies involving the nutrient use efficiency (NUE) and nutrient resorption efficiency (NRE) of desert phreatophytes as affected by different groundwater depths. This work investigated the nitrogen $(\mathrm{N})$, phosphorus $(\mathrm{P})$, and potassium $(\mathrm{K})$ concentrations in leaf, stem, and assimilating branch, as well as the NUE and NRE of the phreatophytic Alhagi sparsifolia. The plant was grown at groundwater depths of 2.5, 4.5, and 11.0 m during 2015 and 2016 in a desertoasis transition ecotone at the southern rim of the Taklimakan Desert in northwestern China. Results show that the leaf, stem, and assimilating branch $\mathrm{P}$ concentrations of $A$. sparsifolia at $4.5 \mathrm{~m}$ groundwater depth were significantly lower than those at 2.5 and $11.0 \mathrm{~m}$ groundwater depths. The $\mathrm{K}$ concentrations in different tissues of A. sparsifolia at $4.5 \mathrm{~m}$ groundwater depth were significantly higher than those at 2.5 and $11.0 \mathrm{~m}$ groundwater depths. Conversely, the NRE of $\mathrm{P}$ in A. sparsifolia was the highest among the three groundwater depths, while that of $\mathrm{K}$ in $A$. sparsifolia was the lowest among the three groundwater depths in 2015 and 2016. The N concentration and NUE of N, P, and K in A. sparsifolia, however, were not influenced by groundwater depth. Further analyses using structural equation models showed that groundwater depth had significant effects on the $\mathrm{P}$ and $\mathrm{K}$ resorption of $A$. sparsifolia by changing soil $\mathrm{P}$ and senescent leaf $\mathrm{K}$ concentrations. Overall, our results suggest groundwater 
depths affect $\mathrm{P}$ and $\mathrm{K}$ concentrations and resorption but not their utilization in a desert phreatophyte in its hyper-arid environment. This study provides a new insight into the phreatophytic plant nutrient cycle strategy under a changing external environment in a hyper-arid ecosystem.

Keywords: nutrient resorption, Alhagi sparsifolia, groundwater table, internal nutrient cycling, desert ecosystem

\section{INTRODUCTION}

Nutrient utilization and resorption are vital for plant growth and ecosystem processes in various ecosystems (Aubrey et al., 2012; Zhao et al., 2017; Wang et al., 2020). First, the total net primary production per unit nutrient absorption is described as nutrient use efficiency (NUE) (Vitousek, 1982). NUE is defined as the product of the mean residence time (MRT) of nutrients in plants and nutrient productivity (NP), which is the rate of biomass increase per unit nutrient in plants (Berendse and Aerts, 1987); a functional interpretation of NUE is considered in accordance with different nutrient use strategies: high NP is strongly associated with low MRT and NP is not related to MRT (Eckstein and Karlsson, 2001; Yuan et al., 2008). Previous studies showed that NUE is affected by nutrient availability and species. For example, NUE decreases as nutrient availability increases (Vitousek, 1982). The effect of species on NUE remains unclear, with one report suggesting that the NUE of C4 grass (Chloris virgata) is higher than that of the C3 grass (Leymus chinensis) despite nitrogen treatments in the temperate grasslands in northern China (Yuan et al., 2007), and the NUE of tree species is influenced by species but not by $\mathrm{N}$ availability (Aubrey et al., 2012). Other suggested that the NUE of woody shrubs and perennial herbs are similar among species and different habitats (high and low water supply) in a typical agropastoral ecotone in the central part of Inner Mongolia Autonomous Region, China (Yuan et al., 2007). Thus, knowledge gap on the roles of species type and nutrient availability in affecting NUE still exists in various ecosystems.

Nutrient resorption from senescing tissues to green tissues has important consequences for plants that live in nutrientlimited habitats. Nutrient resorption helps plants re-use nutrients directly to become less dependent on external nutrient concentrations (Aerts and Chapin, 2000; Wang et al., 2014, 2020; Zhao et al., 2017; Huang et al., 2018). Hence, nutrient resorption is an important mechanism of nutrient conservation in plants. Nutrient resorption efficiency (NRE) is a crucial indicator of internal nutrient recycling in plants (Aerts, 1996; Killingbeck, 1996). The NRE of plants is the percentage of nitrogen (N, P, and $\mathrm{K})$ removed from senescing tissues. On a global scale, the mean $\mathrm{N}$ and $\mathrm{P}$ resorption efficiencies from senescent to young leaves of terrestrial plants are approximately 62 and 65\%, respectively (Vergutz et al., 2012). NRE is usually higher in nutrient-limited habitats than in nutrient-rich ones (Killingbeck, 1996; Yuan and Chen, 2009). Recently, evidence has suggested that NRE is affected by climate, soil/leaf nutrient and stoichiometry, plant functional group, plant age, spatial pattern, and land utilization (Brant and Chen, 2015; Netzer et al., 2017; Xu et al., 2017; Zhao et al., 2017; Wang et al., 2020). Previous studies have shown that increasing water condition decreases the NRE of N, but increases that of $\mathrm{P}$ of three graminoid species, Agropyron cristatum, Achnatherum sibiricum, and Stipa grandis, and one forb species, Potentilla bifurca in Inner Mongolia, China (Lü and Han, 2010). Huang et al. (2018) reported that the NRE of N and $\mathrm{P}$ of three life-form plants (five spring annuals, two summer annuals and two shrubs) are not influenced by increasing water condition in a temperate desert in China. Hence, it is unclear if changing water condition affects NRE of plants in natural environment.

Phreatophytes are largely distributed worldwide except in Antarctica. The deep roots of phreatophytic plants depend on access to groundwater as a major source of nutrients and water (Arndt et al., 2004; Zeng et al., 2006; Thomas, 2014). However, with intensive human intervention, increasing anthropogenic water use intensifies groundwater limitation (Antunes et al., 2018). Groundwater table is gradually lowered in desert oasis transition ecotones, indicating the increasing shortage of water resources (Liu, 2007). Thus, limited plant access to groundwater caused by groundwater lowering is expected to have a major impact on plant nutrient utilization and absorption. Therefore, nutrient utilization and absorption of phreatophytes in nutrient-deficient deserts in response to the declining groundwater depth should be investigated to restore sparse phreatophytes and enhance protection for fragile arid desert ecosystems.

The Taklimakan Desert is the second largest shifting desert in the world and the largest desert in China. As a dominant perennial phreatophyte grown in arid and semi-arid regions between oasis and deserts, Alhagi sparsifolia Shap. can stabilize sand dunes, prevent land erosion, and thus support fragile desert ecosystems (Zeng and Liu, 2012; Li et al., 2015; Zhang et al., 2018a,b). A. sparsifolia is a leguminous plant that can fix atmospheric $\mathrm{N}_{2}$ (Arndt et al., 2004). It is also an economically important species, which can be used as a livestock source by local farmers in winter (Li et al., 2013; Zhang et al., 2018b). The deep root system of $A$. sparsifolia can reach groundwater, which is the major source of water and nutrients (Arndt et al., 2004; Zeng et al., 2006). Our previous study found that the declining water table affects the biomass, leaf physiological parameters, leaf nutrient, root characteristics, clonal growth, and propagation traits of A. sparsifolia (Gui et al., 2013; Zeng et al., 2013; Li et al., 2015; Zhang et al., 2018a).

Although changes in the NP, MRT, and NUE of nitrogen (N) have been widely explored, variations in the NUE of phosphorus (P) and potassium $(\mathrm{K})$ in plants have been seldom investigated. Most studies have assessed nutrient resorption in woody, deciduous, and evergreen plants in response to environmental factors. However, only a few ones have investigated N, P, and K 
utilization and resorption in desert phreatophytes with a deep root system in a reduced groundwater depth in a hyper-arid region. In the present study, we hypothesize that varying groundwater depth can affect variations of NUE and NRE of N, $\mathrm{P}$, and $\mathrm{K}$ in $A$. sparsifolia because of the changes in $\mathrm{N}, \mathrm{P}$, and $\mathrm{K}$ concentrations in A. sparsifolia in a hyper-arid desert ecosystem. Desert phreatophytes, such as A. sparsifolia, can adjust NUE and NRE to adapt to declining groundwater depth in a hyper-arid desert ecosystem.

\section{MATERIALS AND METHODS}

\section{Study Area}

The study site is located at the Cele National Station of Observation and Research for Desert and Grassland Ecosystem $\left(37^{\circ} 00.77^{\prime \prime} \mathrm{N}, 80^{\circ} 43.45^{\prime \prime} \mathrm{E}\right.$, Supplementary Figure 1) at the southern edge of the Taklimakan Desert in the Xinjiang Uyghur Autonomous Region of China. Cele Station located in the desert-oasis transition ecotone is characterized by a $5-10 \mathrm{~km}$ belt of sparse phreatophytic species dominated by A. sparsifolia (Zeng et al., 2013). The groundwater depth ranges from 2.5 to $15.0 \mathrm{~m}$ in this area. The study site has an elevation of $1366 \mathrm{~m}$ (asl), a mean annual temperature of $11.9^{\circ} \mathrm{C}$, a mean annual potential evaporation of $2600 \mathrm{~mm}$, and a mean annual precipitation of $35 \mathrm{~mm}$ (Gui et al., 2013; Liu et al., 2016). The climate is hyper-arid, with hot and dry summers and cold and dry winters. Extreme temperatures can reach $41.9^{\circ} \mathrm{C}$ in summer and $-31^{\circ} \mathrm{C}$ in winter. Soils are sandy, and their bulk density is $1.35 \mathrm{~g} / \mathrm{cm}^{3}$ (Liu et al., 2013, 2016). Soil C, $\mathrm{N}$, and $\mathrm{P}$ concentrations at $2.5 \mathrm{~m}$ groundwater depth are similar to those at $4.5 \mathrm{~m}$ groundwater depth, while soil $\mathrm{C}, \mathrm{N}$, and $\mathrm{P}$ concentrations at 2.5 and $4.5 \mathrm{~m}$ groundwater depths are significantly lower than those at 11.0 groundwater depth (Zhang et al., 2018a).

Three sites with varying groundwater depths were selected: $2.5 \mathrm{~m} \quad\left(37^{\circ} 01^{\prime} 18^{\prime \prime} \mathrm{N}, \quad 80^{\circ} 42^{\prime} 29^{\prime \prime} \mathrm{E}\right), \quad 4.5 \mathrm{~m} \quad\left(37^{\circ} 00^{\prime} 40^{\prime \prime} \mathrm{N}\right.$, $\left.80^{\circ} 42^{\prime} 13^{\prime \prime} \mathrm{E}\right)$, and $11.0 \mathrm{~m} \quad\left(37^{\circ} 00^{\prime} 33^{\prime \prime} \mathrm{N}, \quad 80^{\circ} 42^{\prime} 25^{\prime \prime} \mathrm{E}\right.$, Supplementary Figure 2). In each research area, the groundwater depth in a well was measured every month. The fluctuation in groundwater depth was minor from April to October in 2015 and 2016. Each site has a large area of approximately 2 ha. At each sampling stage, three plots with an area of $9 \mathrm{~m}^{2}$ were randomly selected at each site.

\section{Field Sampling and Chemical Analysis}

At each groundwater depth, three A. sparsifolia plants in different plots with similar canopy sizes, heights, and numbers of stems were selected each month from June to October 2015 and 2016. In the experimental period, nine plots were sampled nine times per month. Thus, 45 samplings in 2015 and 2016 were performed. During sampling, plant above-ground was collected by chipping at the ground level and further separating into different tissues, including leaf, stem, and assimilating branch. The samples were oven-dried at $105^{\circ} \mathrm{C}$ for $15 \mathrm{~min}$ and at $70^{\circ} \mathrm{C}$ to a constant weight. The dry biomass of leaf, stem, and the assimilating branches of $A$. sparsifolia were weighed. All samples were subsequently ground using a miller and sieved through a $1 \mathrm{~mm}$ mesh screen for chemical element analysis. Plant tissues were digested using $0.02 \mathrm{M}$ sulfuric acid, and $\mathrm{N}$ concentrations were determined by the Kjeldahl acid-digestion method (Sparks et al., 1996). The $\mathrm{P}$ and $\mathrm{K}$ concentrations were determined using the colorimetric analysis and a flame analyzer (2655-00, Chicago, United States), respectively, after digestion with sulfuric acid (Thomas et al., 1967).

\section{Definition and Calculations}

NUE $\left(\mathrm{g} \mathrm{g}^{-1}\right)$ is calculated as the product of NP $\left(\mathrm{g} \mathrm{g}^{-1}\right.$ year $\left.^{-1}\right)$ and MRT (year) of nutrients (Berendse and Aerts, 1987; Garnier and Aronson, 1998; Yasumura et al., 2002; Yuan et al., 2004, 2006, 2007; Norby and Iversen, 2006). NP was calculated for short intervals (Eckstein and Karlsson, 2001; Yuan et al., 2004, 2007) in accordance with the following equation:

$$
\mathrm{NP}=\frac{M_{2}-M_{1}}{t_{2}-t_{1}} \cdot \frac{\ln N_{2}-\ln N_{1}}{N_{2}-N_{1}}
$$

where $M$ is biomass of $A$. sparsifolia and $N$ is the average leaf, stem, and assimilating branch $\mathrm{N}$ concentration, respectively, in two consecutive harvests conducted at times $t_{1}$ and $t_{2}$. The mean annual nutrient concentration was estimated as a weighted average in the entire year of 2015 and 2016. Besides, MRT was calculated as the ratio between the average nutrient concentration of leaf, stem, and assimilating branch of $A$. sparsifolia and the annual nutrient losses of A. sparsifolia (Eckstein and Karlsson, 2001; Norby and Iversen, 2006). Nutrient losses were determined on the nutrient concentration of the aboveground dead A. sparsifolia harvested in October 2015 and 2016.

Nutrient concentrations in green and senescing tissues of A. sparsifolia were used to calculate N-resorption efficiency (NRE, $\%)=[(\mathrm{Ng}-\mathrm{Ns}) / \mathrm{Ng}] \cdot 100$, where $\mathrm{Ng}$ and $\mathrm{Ns}$ are the nutrient concentrations in green and senescing tissues of A. sparsifolia, respectively. Nutrient concentration in senescing tissues of A. sparsifolia (October 2015 and 2016) was used as a direct indicator of nutrient resorption proficiency (NRP), that is, the extent to which nutrient concentration is reduced in senescent tissues. A high resorption proficiency usually indicates low nutrient concentration in senesced tissues (Killingbeck, 1996; Richardson et al., 2005; Yuan et al., 2007; Wang et al., 2014).

\section{Data Analysis}

One-way ANOVA with Tukey's test was carried out for the multiple comparisons of $\mathrm{N}, \mathrm{P}$, and $\mathrm{K}$ concentrations, NP, MRT, NUE, NRE, and NRP at different groundwater depths to test statistical significance $(p<0.05)$. Analyses were performed using SPSS 19.0. Piecewise structural equation modeling (piecewise SEM) was used to statistically tease apart and quantify direct and indirect effects of groundwater depth on plant leaf nutrient, nutrient utilization and resorption using $\mathrm{R}$ software (version 4.0.3) with the package "piecewiseSEM" (Lefcheck, 2016). D-separation test of Piecewise SEM was used to evaluate whether the causal model misses important links and $p>0.05$ indicates that the model is acceptable (Shipley, 2002). 


\section{RESULTS}

\section{$\mathrm{N}, \mathrm{P}$, and $\mathrm{K}$ Concentrations of \\ A. sparsifolia as Affected by Groundwater Depth}

The $\mathrm{P}$ and $\mathrm{K}$ concentrations in the leaf, stem, and assimilating branch of $A$. sparsifolia were significantly affected by groundwater depth (Figures 1, 2). The $\mathrm{P}$ concentration in different tissues of A. sparsifolia at $4.5 \mathrm{~m}$ groundwater were significantly lower than those at 2.5 and $11.0 \mathrm{~m}$ groundwater depths (Figure 1). The $\mathrm{K}$ concentration in all three parts of $A$. sparsifolia at $4.5 \mathrm{~m}$ groundwater depth were the highest among the three groundwater depths. The $\mathrm{K}$ concentration in all parts of
A. sparsifolia at $2.5 \mathrm{~m}$ groundwater depth were greater than those at $11.0 \mathrm{~m}$ groundwater depth (Figure 2). However, the $\mathrm{N}$ concentration in leaf, stem, and assimilating branch of A. sparsifolia were not influenced by groundwater depth in both years (Figure 3).

\section{$\mathrm{N}, \mathrm{P}$, and $\mathrm{K}$ Use and Resorption Strategies as Affected by Groundwater Depth}

Groundwater depth significantly influenced the $\mathrm{P}$ resorption parameters, such as NRE and NRP of $\mathrm{P}$ but not the P utilization parameters, such as NP, MRT, and NUE of P (Table 1). The NRE of $\mathrm{P}$ was significantly greater at $4.5 \mathrm{~m}$ groundwater depth

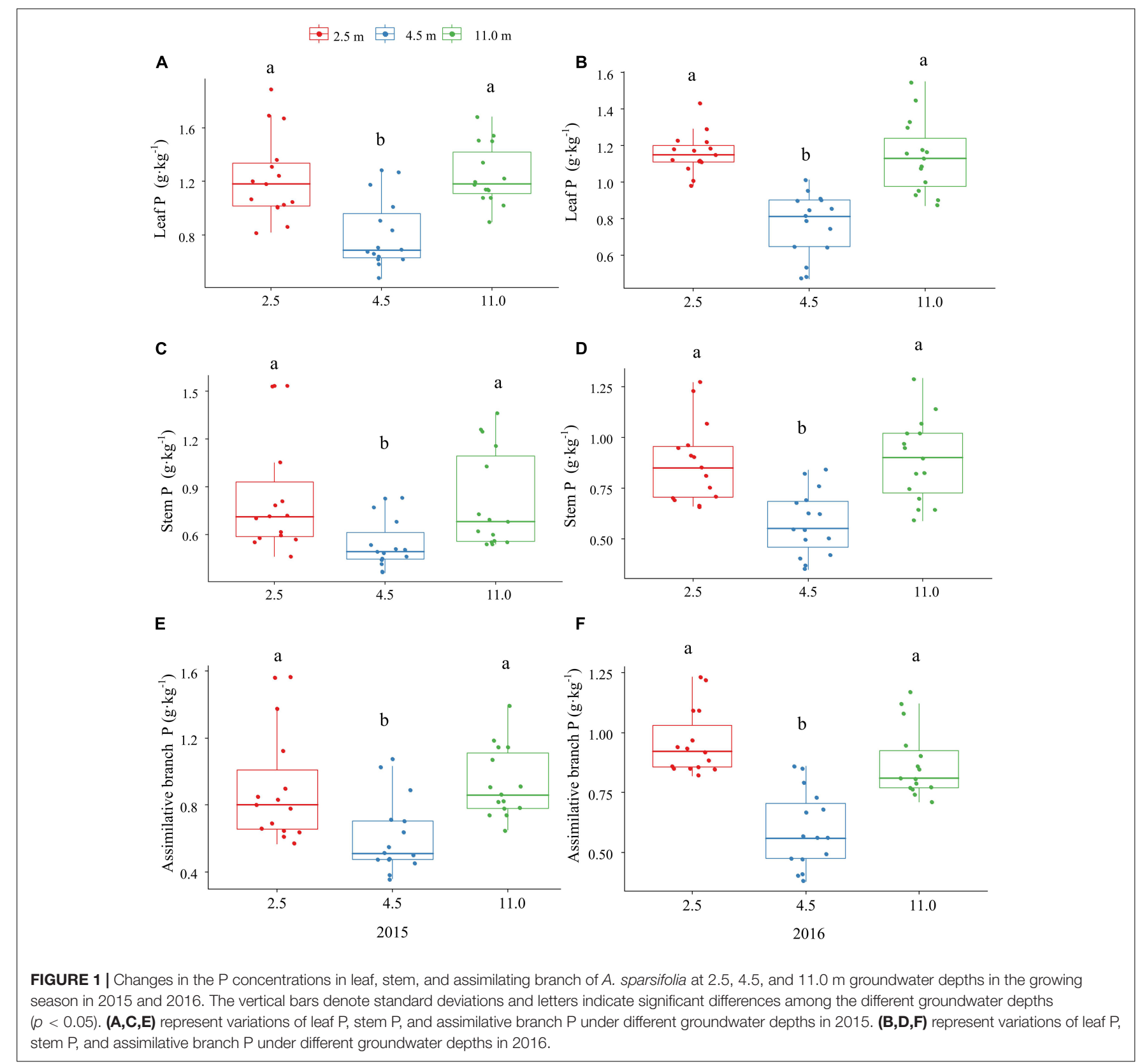



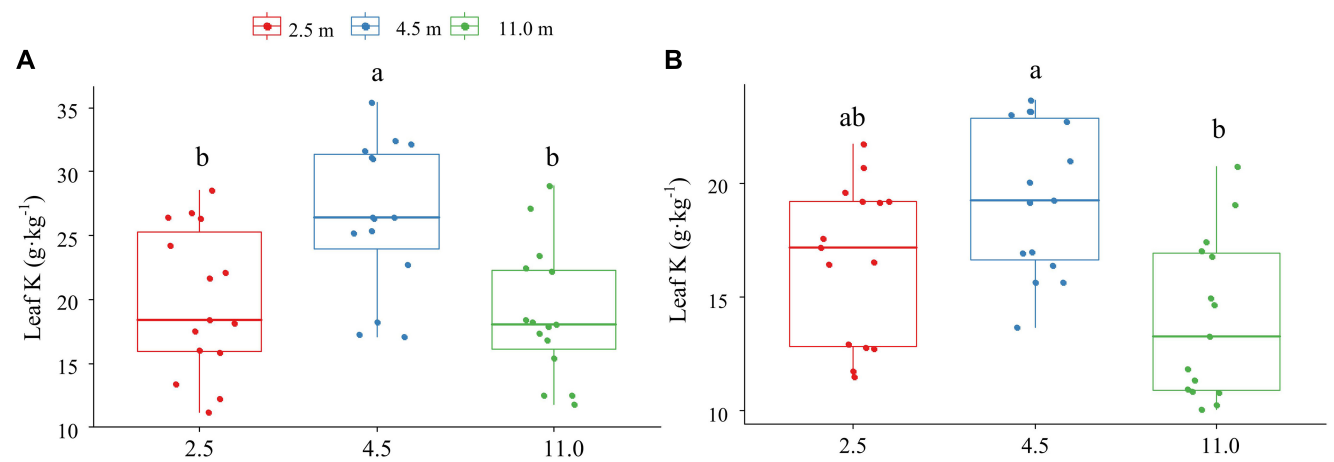

C

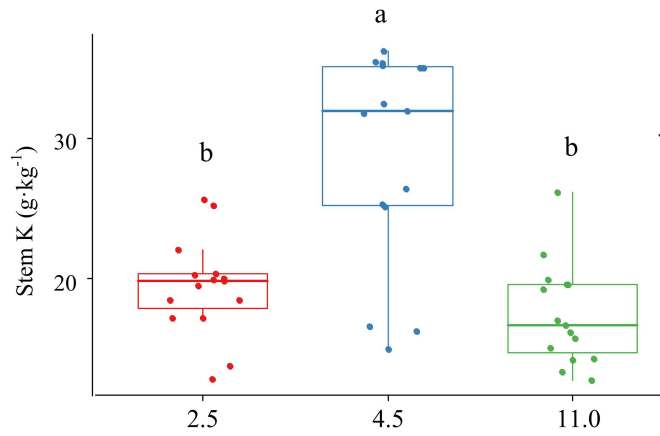

E

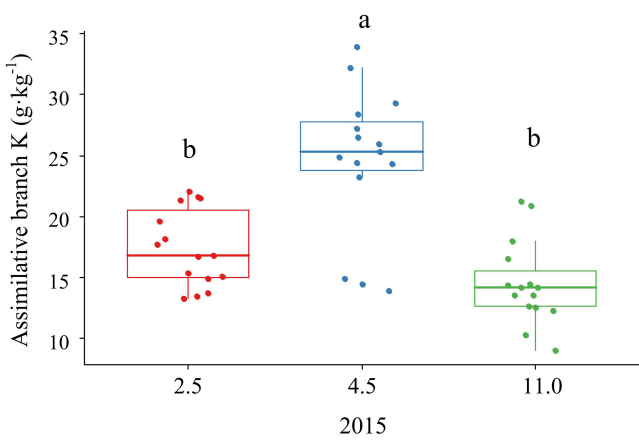

D
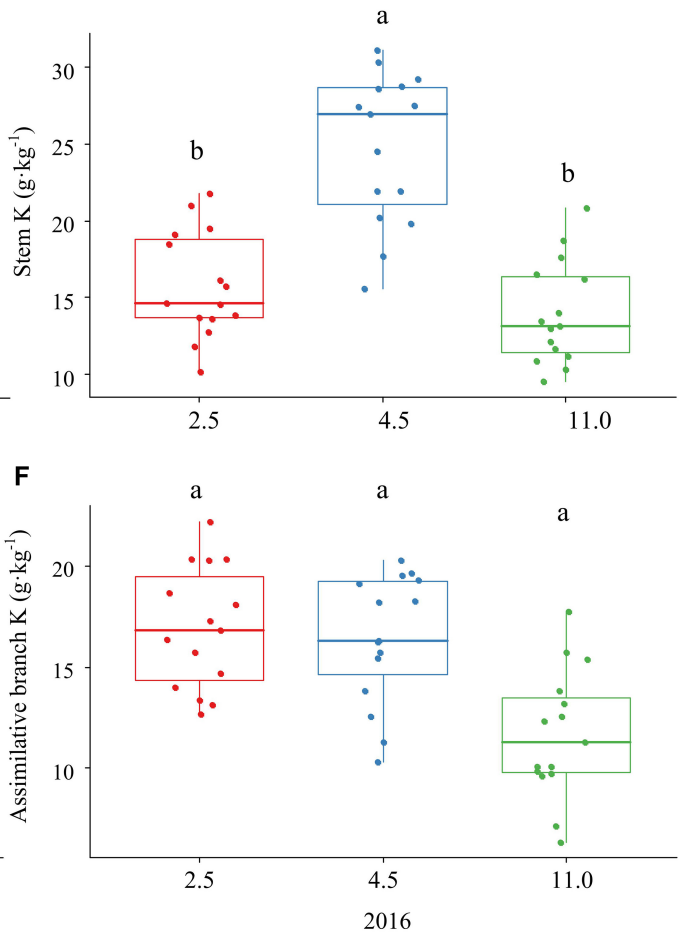

FIGURE 2 | Changes in the $K$ concentrations in leaf, stem, and assimilating branch of $A$. sparsifolia at 2.5, 4.5, and $11.0 \mathrm{~m}$ groundwater depths in the growing season in 2015 and 2016. The vertical bars denote standard deviations and letters indicate significant differences among the different groundwater depths $(p<0.05)$. (A,C,E) represent variations of leaf $K$, stem $K$, and assimilative branch $\mathrm{K}$ under different groundwater depths in 2015. (B,D,F) represent variations of leaf K, stem K, and assimilative branch K under different groundwater depths in 2016.

than at 2.5 and $11.0 \mathrm{~m}$ groundwater depths in 2015 and 2016, corresponding to the lower NRP of $\mathrm{P}$ at $4.5 \mathrm{~m}$ groundwater depth than at 2.5 and $11.0 \mathrm{~m}$ groundwater depths in 2015 and 2016, respectively. Groundwater depth did not affect the N utilization and resorption parameters, such as NP, MRT, NUE, NRE, and NRP of N in A. sparsifolia in both years (Table 2).

Similarly, groundwater depth significantly affected the $\mathrm{K}$ resorption parameters, such as NRE and NRP of $K$, but not the $\mathrm{K}$ utilization parameters, such as NP, MRT, and NUE (Table 3). The NRE of $K$ at $11.0 \mathrm{~m}$ groundwater depth was the greatest among the three groundwater depths, and the NRP at $11.0 \mathrm{~m}$ groundwater depth was the lowest in 2015. The NRE of $\mathrm{K}$ at $4.5 \mathrm{~m}$ groundwater depth was the lower than that at 2.5 and
$11.0 \mathrm{~m}$ groundwater depth, corresponding to the highest NRP at $4.5 \mathrm{~m}$ groundwater depth in 2015 .

\section{Factors Affecting Variation in N, P, and K Resorption}

The factors affecting variation in $\mathrm{N}, \mathrm{P}$, and $\mathrm{K}$ resorption were explored using structural equation models (SEM) (Figure 4). The model explained 57,66 , and $40 \%$ of the variance in NRE of $\mathrm{N}$, $\mathrm{P}$, and $\mathrm{K}$ (Figures 4A-C). Groundwater depth had no direct and indirect effects on the NRE of N (Figure 4A). The NRE of N was directly affected by green leaf and senesced leaf $\mathrm{N}$ concentrations. In addition, groundwater depth had indirect effect on the NRE of 

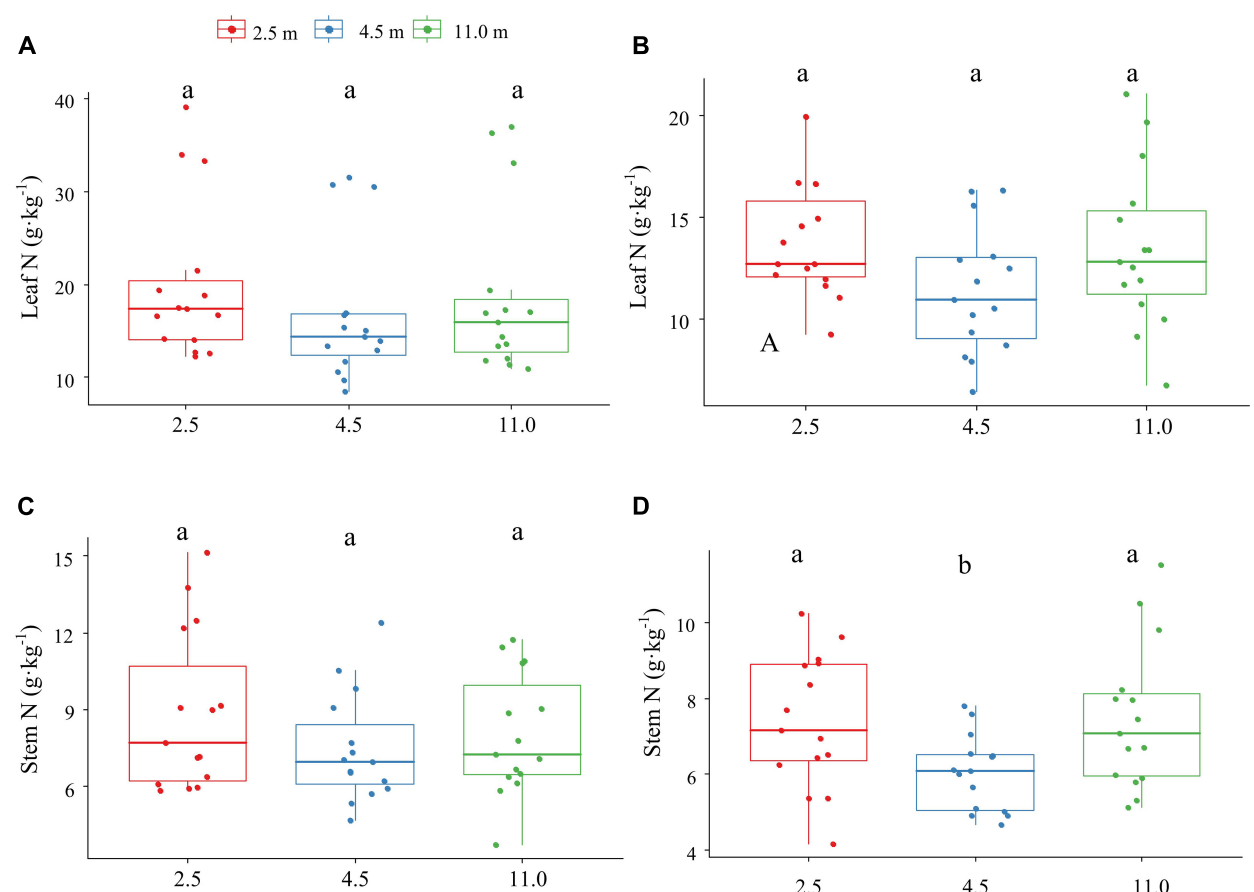

D
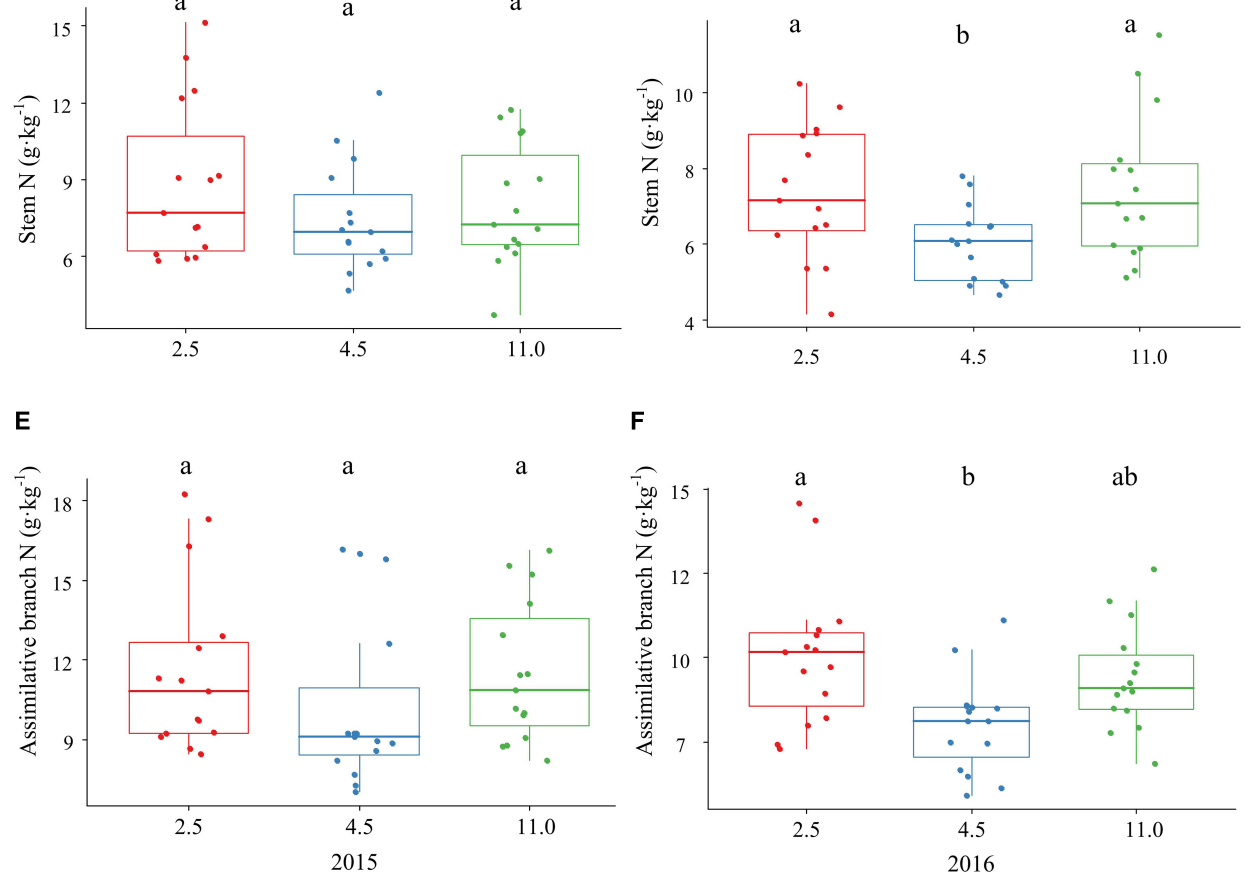

FIGURE 3 | Changes in the $\mathrm{N}$ concentrations in leaf, stem, and assimilating branch of $A$. sparsifolia at 2.5, 4.5, and $11.0 \mathrm{~m}$ groundwater depths in the growing season in 2015 and 2016. The vertical bars denote standard deviations and letters indicate significant differences among the different groundwater depths

$(p<0.05)$. (A,C,E) represent variations of leaf $N$, stem N, and assimilative branch $N$ under different groundwater depths in 2015. (B,D,F) represent variations of leaf $\mathrm{N}$, stem N, and assimilative branch N under different groundwater depths in 2016.

$\mathrm{P}$ (Figure 4B). The NRE of $\mathrm{P}$ was directly affected by green leaf $\mathrm{P}$ concentrations and soil P concentration. Soil P concentration was most positively related to groundwater depth. Moreover, groundwater depth had an indirect effect on the NRE of $\mathrm{K}$ (Figure 4C). The NRE of $\mathrm{K}$ was directly affected by senesced leaf $\mathrm{K}$ concentration. Besides, senesced leaf $\mathrm{K}$ concentration was negatively related to groundwater depth.

\section{DISCUSSION}

\section{Effect of Groundwater Depth on N, P, and K Concentrations of $A$. sparsifolia}

Our results showed that groundwater depth had a significant effect on $\mathrm{P}$ concentrations in different tissues of phreatophytic
A. sparsifolia. This result is consistent with that of previous studies that leaf $\mathrm{P}$ concentration of $A$. sparsifolia was significantly affected by groundwater depth. This is consistent with the observation that leaf $\mathrm{P}$ concentration of A. sparsifolia at $4.5 \mathrm{~m}$ is lower than those at 2.5 and $11.0 \mathrm{~m}$ groundwater depths in 2015 and 2016 because biomass of A. sparsifolia at $4.5 \mathrm{~m}$ is geater than those at 2.5 and $11.0 \mathrm{~m}$ groundwater depths. Hence, a biomass dilution effect existed in leaf $\mathrm{P}$ concentration of $A$. sparsifolia at $4.5 \mathrm{~m}$ groundwater depths (Zhang et al., 2018a). Moreover, the effect of groundwater depth on leaf $\mathrm{P}$ concentration is likely caused by direct effect of groundwater on soil $\mathrm{P}$ concentration (Figure 4B), which is strongly related to the plant $\mathrm{P}$ concentration of A. sparsifolia (Zhang et al., 2018a). These results are in accordance with previous experiments that soil P concentration 
TABLE 1 | Phosphorus use strategies of $A$. sparsifolia affected by 2.5, 4.5, and 11.0 m groundwater depths in 2015 and 2016.

\begin{tabular}{|c|c|c|c|c|c|}
\hline 2015 & NP $\left(g^{-1}\right.$ year $\left.^{-1}\right)$ & MRT (year) & NUE $\left(g g^{-1}\right)$ & NRE (\%) & $\operatorname{NRP}\left(\mathrm{mg} \mathrm{g}^{-1}\right)$ \\
\hline $2.5 \mathrm{~m}$ & $8.77 \pm 3.10^{a}$ & $1.36 \pm 0.40^{a}$ & $12.68 \pm 6.79^{a}$ & $49.08 \pm 9.76^{a b}$ & $0.83 \pm 0.15^{a}$ \\
\hline $4.5 \mathrm{~m}$ & $4.55 \pm 2.72^{a}$ & $0.97 \pm 0.05^{a}$ & $4.46 \pm 2.81^{a}$ & $50.15 \pm 10.37^{a}$ & $0.49 \pm 0.08^{b}$ \\
\hline $11.0 \mathrm{~m}$ & $3.86 \pm 3.26^{a}$ & $0.95 \pm 0.08^{a}$ & $3.83 \pm 2.81^{\mathrm{a}}$ & $29.15 \pm 2.71^{b}$ & $0.87 \pm 0.08^{a}$ \\
\hline 2016 & $\mathrm{NP}\left(\mathrm{g} \mathrm{g}^{-1}\right.$ year $\left.^{-1}\right)$ & MRT (year) & NUE $\left(g^{-1}\right)$ & NRE (\%) & $\mathrm{NRP}\left(\mathrm{mg} \mathrm{g}^{-1}\right)$ \\
\hline $2.5 \mathrm{~m}$ & $4.38 \pm 1.14^{\mathrm{a}}$ & $1.51 \pm 0.19^{a}$ & $6.48 \pm 1.23^{a}$ & $69.74 \pm 4.75^{b}$ & $0.83 \pm 0.11^{a}$ \\
\hline $4.5 \mathrm{~m}$ & $4.58 \pm 2.46^{a}$ & $1.74 \pm 0.54^{a}$ & $7.46 \pm 3.37^{a}$ & $81.07 \pm 4.32^{a}$ & $0.42 \pm 0.01^{b}$ \\
\hline $11.0 \mathrm{~m}$ & $2.73 \pm 0.59^{a}$ & $2.19 \pm 0.40^{a}$ & $5.91 \pm 1.36^{a}$ & $71.81 \pm 2.78^{a b}$ & $0.84 \pm 0.07^{a}$ \\
\hline
\end{tabular}

Means followed by different letters are significantly different at $p<0.05$.

NP, nutrient productivity; MRT, mean residence time; NUE, nutrient-use efficiency; NRE, nutrient-resorption efficiency; NRP, nutrient-resorption proficiency.

"ab" means that there are no significant differences among $a$, ab, and $b$ at $p<0.05$.

TABLE 2 | Nitrogen use strategies of $A$. sparsifolia affected by 2.5, 4.5, and $11.0 \mathrm{~m}$ groundwater depths in 2015 and 2016

\begin{tabular}{|c|c|c|c|c|c|}
\hline 2015 & NP $\left(g^{-1}\right.$ year $\left.^{-1}\right)$ & MRT (year) & NUE $\left(g \mathbf{g}^{-1}\right)$ & NRE (\%) & $\operatorname{NRP}\left(\mathrm{mg} \mathrm{g}^{-1}\right)$ \\
\hline $2.5 \mathrm{~m}$ & $0.62 \pm 0.20^{a}$ & $1.33 \pm 0.32^{a}$ & $0.86 \pm 0.40^{a}$ & $46.25 \pm 6.20^{a}$ & $11.76 \pm 1.35^{\mathrm{a}}$ \\
\hline $4.5 \mathrm{~m}$ & $0.26 \pm 0.16^{a}$ & $0.94 \pm 0.05^{a}$ & $0.24 \pm 0.16^{a}$ & $55.14 \pm 4.11^{a}$ & $8.43 \pm 0.56^{a}$ \\
\hline $11.0 \mathrm{~m}$ & $0.40 \pm 0.05^{\mathrm{a}}$ & $0.95 \pm 0.07^{a}$ & $0.38 \pm 0.07^{\mathrm{a}}$ & $46.16 \pm 8.29^{a}$ & $11.08 \pm 2.03^{a}$ \\
\hline 2016 & $\mathrm{NP}\left(\mathrm{g} \mathrm{g}^{-1}\right.$ year $\left.^{-1}\right)$ & MRT (year) & NUE $\left(g^{-1}\right)$ & NRE (\%) & $\mathrm{NRP}\left(\mathrm{mg} \mathrm{g}^{-1}\right)$ \\
\hline $2.5 \mathrm{~m}$ & $0.52 \pm 0.16^{a}$ & $1.14 \pm 0.05^{a}$ & $0.59 \pm 0.17^{a}$ & $47.34 \pm 7.44^{\mathrm{a}}$ & $9.37 \pm 1.49^{\mathrm{a}}$ \\
\hline $4.5 \mathrm{~m}$ & $0.42 \pm 0.22^{a}$ & $1.04 \pm 0.15^{\mathrm{a}}$ & $0.43 \pm 0.18^{a}$ & $52.90 \pm 8.69^{a}$ & $7.29 \pm 0.30^{a}$ \\
\hline $11.0 \mathrm{~m}$ & $0.34 \pm 0.09^{a}$ & $1.74 \pm 0.59^{a}$ & $0.60 \pm 0.31^{a}$ & $50.58 \pm 5.31^{a}$ & $9.23 \pm 1.37^{\mathrm{a}}$ \\
\hline
\end{tabular}

Means followed by different letters are significantly different at $p<0.05$.

NP, nutrient productivity; MRT, mean residence time; NUE, nutrient-use efficiency; NRE, nutrient-resorption efficiency; NRP, nutrient-resorption proficiency.

"a" means that there is no significant difference in the three groundwater depths.

TABLE 3 | Potassium use strategies of $A$. sparsifolia affected by 2.5, 4.5, and 11.0 m groundwater depths in 2015 and 2016.

\begin{tabular}{|c|c|c|c|c|c|}
\hline 2015 & NP $\left(g^{-1}\right.$ year $\left.^{-1}\right)$ & MRT (year) & NUE $\left(g g^{-1}\right)$ & NRE (\%) & $\operatorname{NRP}\left(\mathrm{mg} \mathrm{g}^{-1}\right)$ \\
\hline $2.5 \mathrm{~m}$ & $7.30 \pm 4.17^{\mathrm{a}}$ & $0.98 \pm 0.29^{a}$ & $7.93 \pm 5.47^{a}$ & $17.92 \pm 2.14^{a b}$ & $16.78 \pm 1.12^{b}$ \\
\hline $4.5 \mathrm{~m}$ & $4.21 \pm 2.91^{\mathrm{a}}$ & $0.76 \pm 0.11^{a}$ & $3.15 \pm 2.36^{a}$ & $7.21 \pm 4.95^{b}$ & $31.62 \pm 1.29^{\mathrm{a}}$ \\
\hline $11.0 \mathrm{~m}$ & $4.04 \pm 2.44^{\mathrm{a}}$ & $0.65 \pm 0.08^{a}$ & $2.67 \pm 1.38^{\mathrm{a}}$ & $25.49 \pm 5.91^{a}$ & $12.11 \pm 0.42^{C}$ \\
\hline 2016 & $\mathrm{NP}\left(\mathrm{g} \mathrm{g}^{-1}\right.$ year $\left.^{-1}\right)$ & MRT (year) & NUE $\left(g^{-1}\right)$ & NRE (\%) & $\mathrm{NRP}\left(\mathrm{mg} \mathrm{g}^{-1}\right)$ \\
\hline $2.5 \mathrm{~m}$ & $0.95 \pm 0.47^{a}$ & $0.85 \pm 0.15^{a}$ & $0.76 \pm 0.31^{a}$ & $13.66 \pm 6.33^{a}$ & $17.62 \pm 0.72^{a}$ \\
\hline $4.5 \mathrm{~m}$ & $1.01 \pm 0.52^{a}$ & $0.70 \pm 0.04^{a}$ & $0.71 \pm 0.38^{a}$ & $19.96 \pm 1.07^{\mathrm{a}}$ & $20.33 \pm 3.09^{a}$ \\
\hline $11.0 \mathrm{~m}$ & $0.41 \pm 0.27^{a}$ & $1.30 \pm 0.51^{a}$ & $0.47 \pm 0.28^{a}$ & $17.41 \pm 9.12^{\mathrm{a}}$ & $14.64 \pm 4.58^{a}$ \\
\hline
\end{tabular}

Means followed by different letters are significantly different at $p<0.05$.

NP, nutrient productivity; MRT, mean residence time; NUE, nutrient-use efficiency; NRE, nutrient-resorption efficiency; NRP, nutrient-resorption proficiency.

is the key factor affecting the growth and salt Tolerance of A. sparsifolia in different habitat in Northwest China (Zhang et al., 2018b).

In addition, $\mathrm{K}$ concentration in phreatophytic $A$. sparsifolia was significantly affected by groundwater depth. The leaf, stem, and assimilating branch $\mathrm{K}$ concentrations of $A$. sparsifolia at $4.5 \mathrm{~m}$ groundwater depth were significantly higher than those at 2.5 and $11.0 \mathrm{~m}$ groundwater depths and is mainly due to the direct negative effect of groundwater depth on senesced leaf $\mathrm{K}$ concentration (Figure $\mathbf{4 C}$ ) and leaf $\mathrm{K}$ concentration is affected by soil $\mathrm{K}$ concentration (Zeng et al., 2001) and water stress (Saneoka et al., 2004). Moreover, N concentration in the phreatophytic $A$. sparsifolia was unaffected by various groundwater depth because this plant is a leguminous plant, and more than $80 \%$ of its total leaf $\mathrm{N}$ is fixed by the atmosphere (Arndt et al., 2004).

\section{Effect of Groundwater Depth on the Nutrient Resorption of $A$. sparsifolia}

Herein, our data partly supported the hypothesis that groundwater depth had a significant influence on the nutrient resorption (NRE of $\mathrm{P}$ and $\mathrm{K}$ ) of the phreatophytic A. sparsifolia, but its effect on nutrient utilization (NUE of N, P, and K) was minimal. Groundwater depth significantly affected the NRE of $\mathrm{P}$ in A. sparsifolia. Although groundwater depth had no direct effect of the NRE of $\mathrm{P}$, it had an indirect effect on the NRE of $\mathrm{P}$ via soil $\mathrm{P}$ concentration that is mostly determined by groundwater depth (Figure 4). This result is similar to that of our previous experiments that leaf $\mathrm{P}$ concentration in A. sparsifolia is positively linked to soil $\mathrm{P}$ concentration under different groundwater depths (Zhang et al., 2018a). Similar reports have noted that the NRE of $\mathrm{P}$ in herbaceous species decreases with 


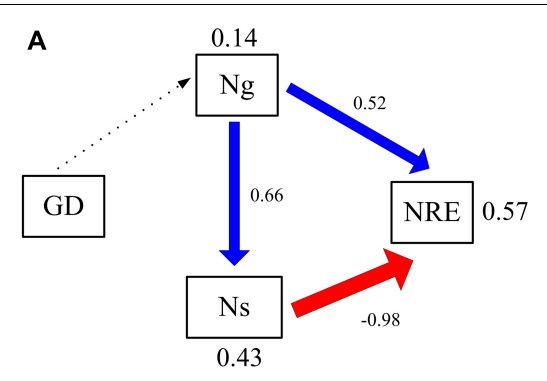

Fisher's $\mathrm{C}=8.95, p=0.06$

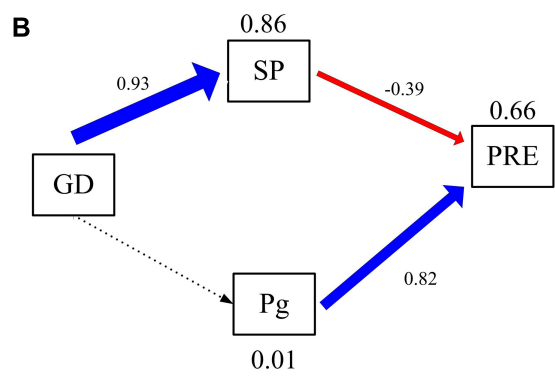

Fisher's $C=4.79, p=0.31$

C

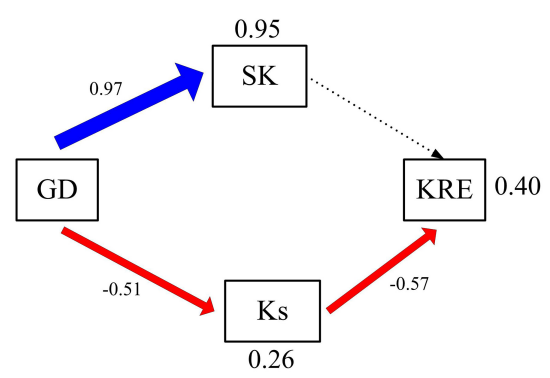

Fisher's $\mathrm{C}=7.87, p=0.10$

FIGURE 4 | Controlling factors analysis of leaf resorption efficiency using the structural equation model. Significant regressions are indicated by solid lines $(p<0.05)$ and nonsignificant regressions by dashed lines. The thickness of the significant paths has been scaled based on the magnitude of the standardized regression coefficient. Black arrows denote positive relationships, and red arrows negatives ones. GD, groundwater depth; Ng, nitrogen concentrations of green leaves; Ns, nitrogen concentrations of senesced leaves; NRE, nitrogen resorption efficiency; SP, soil available phosphorus concentration; Pg, phosphorus concentrations of green leaves; PRE, phosphorus resorption efficiency; SP, soil available potassium concentration; Ks, potassium concentrations of senesced leaves; KRE, potassium resorption efficiency. (A) Controlling factors analysis of leaf nitrogen resorption efficiency. (B) Controlling factors analysis of leaf phosphorus resorption efficiency.

(C) Controlling factors analysis of leaf potassium resorption efficiency.

increasing soil $\mathrm{P}$ concentration as indicated by global data analysis (Wang et al., 2018).

The NRE of $\mathrm{P}$ in Cleistogenes squarrosa (Trin. ex Ledeb.) Keng is significantly affected by green and senesced leaf $\mathrm{P}$ concentrations in overgrazing treatments (Wang et al., 2020). Herein, the NRE of $\mathrm{P}$ in A. sparsifolia at $4.5 \mathrm{~m}$ groundwater depth was significantly higher than that at $2.5 \mathrm{~m}$ (Table 1), suggesting that $A$. sparsifolia at $4.5 \mathrm{~m}$ groundwater depth could have translocated more $\mathrm{P}$ from the senescing tissues to the green tissues to support plant growth as indicated in our previous report that the soil $\mathrm{P}$ concentrations between 4.5 and $2.5 \mathrm{~m}$ groundwater depths in the same area were not significantly different (Zhang et al., 2018a). This funding is also supported by the lower $\mathrm{P}$ concentration in senescent tissues (NRP of $\mathrm{P}$ ) at $4.5 \mathrm{~m}$ groundwater depth than that at $2.5 \mathrm{~m}$ (Table 1 and Figure 1). The NRE of $\mathrm{P}$ in $A$. sparsifolia at $4.5 \mathrm{~m}$ groundwater depth was significantly greater than that at $11.0 \mathrm{~m}$ groundwater depth because soil available $\mathrm{P}$ concentration at $4.5 \mathrm{~m}$ groundwater depth is significantly lower than those at $11.0 \mathrm{~m}$ groundwater depth (Zhang et al., 2018a). The results suggested that $A$. sparsifolia in the P-limited habitat adopt better nutrient conservation mechanisms to reduce nutrient loss through internal nutrient cycling. This result is also consistent with the observation that desert plants in nutrientpoor environments usually rely on high NRE to alleviate nutrient limitation (Drenovsky and Richards, 2006; Vergutz et al., 2012; Brant and Chen, 2015).

In the present study, the observed NRE of $\mathrm{P}$ in A. sparsifolia under different groundwater depths ranges from 29.2 to $81.1 \%$ and it similar to that of a legume (Oxytropis sp.) that grows on the Tibetan Changtang Plateau (Zhao et al., 2017). The $\mathrm{P}$ resorption efficiency in 2015 was $29.15-50.15 \%$, which was lower than the global value of $64.9 \%$; the $\mathrm{P}$ resorption efficiency values in 2016 was $69.74-81.07 \%$ and greater than the global P resorption efficiency (Vergutz et al., 2012). There are significant difference between NRE of P in A. sparsifolia in 2015 and 2016 and interactive effects of groundwater depth and year were found on NRE of P in A. sparsifolia in 2015 and 2016 (Supplementary Table 2). It is important to note that leaf $\mathrm{P}$ resorption enhances with increasing mean annual precipitation (Brant and Chen, 2015). Leaf P resorption efficiencies of woody plants increase with mean annual precipitation at the global scale (Yuan and Chen, 2009), and P resorption efficiencies of a legume (Oxytropis sp.), grass (S. purpurea), and forb (Potentilla bifurca L) are enhanced with increasing precipitation on the Tibetan Changtang Plateau (Zhao et al., 2017). Therefore, the significant difference between NRE of P in A. sparsifolia in 2015 and 2016 was likely due to the limited precipitation in $2015(34.2 \mathrm{~mm})$, which was $26.9 \%$ less than that in 2016 (43.4 mm, Supplementary Table 1). These results are in accordance with previous findings 
of Ren et al. (2018) who reported that the nutrient resorption of two perennial grasses, Cleistogenes songorica, and Stipa breviflora, and one perennial semi-shrub, Artemisia frigida, to warming and nitrogen fertilization could be regulated by natural precipitation variations in a desert grassland in Inner Mongolia, northern China. These results are also consistent with the observation that leaf $\mathrm{P}$ resorption in Lucerne enhances with increasing water conditions in the greenhouse (Lu et al., 2019).

Similarly, groundwater depth had no direct effect on the NRE of $\mathrm{K}$, had an indirect effect on the NRE of $\mathrm{K}$ via the senesced leaf $\mathrm{K}$ concentration (Figure 4). The NRE of $\mathrm{K}$ in A. sparsifolia at $11.0 \mathrm{~m}$ groundwater depth was the higher than 2.5 and $4.5 \mathrm{~m}$ groundwater depths, while the NRP of K in A. sparsifolia at $11.0 \mathrm{~m}$ groundwater depth was the lower than the 2.5 and $4.5 \mathrm{~m}$ groundwater depths in 2015 (Table 3). As such, A. sparsifolia at $11.0 \mathrm{~m}$ groundwater depth had a greater NRE of $\mathrm{K}$ than others, resulting in the lowest $\mathrm{K}$ concentration in senescent tissues (NRP of K) to adapt to the largest groundwater depth at the southern rim of the Taklimakan Desert (Figure 2). The NRE of $\mathrm{K}$ in A. sparsifolia under different groundwater depths ranged from 7.2 to $25.5 \%$ in 2015 and 13.7 to $20.0 \%$ in 2016 , respectiely, which was significantly lower than the highest global K resorption efficiency of $70.1 \%$ (Vergutz et al., 2012) and in lucerne that varies from 21.0 to $49.8 \%$ with an average of $36.9 \%$ (Wang et al., 2014). Besides, no significant difference between NRE of K was observed in A. sparsifolia in 2015 and 2016 (Supplementary Table 2). These results may because sand soil in the desert had higher $\mathrm{K}$ concentration and lower soil $\mathrm{N}$ and $\mathrm{P}$ concentrations (Liu et al., 2013), and the NRE in nutrient-rich habitats is lower than that in nutrient-poor habitats, compared with other soil types (Killingbeck, 1996; Yuan and Chen, 2009). Hence, the low NRE of $\mathrm{K}$ in A. sparsifolia was attributed to the high $\mathrm{K}$ availability in soil and the high $\mathrm{K}$ availability in soil results in no significant difference between NRE of K in A. sparsifolia in 2015 and 2016. In the present study, groundwater depth had no effect on the NRE of N (Figure 4). The NRE of $\mathrm{N}$ in A. sparsifolia under different groundwater depths was $46.1-55.1 \%$ and significantly lower than the highest global $\mathrm{N}$ resorption efficiency (62.1\%) (Vergutz et al., 2012) and the NRE in grass (Stipa purpurea; 74.4\%), sedge (Carex moorcroftii; 73.7\%), and forb (Potentilla bifurca L; 73.5\%) (Zhao et al., 2017). However, the observed values were similar to that of a legume (Oxytropis sp.) on the Tibetan Changtang Plateau (47.2\%) (Zhao et al., 2017) and higher than that of lucerne (a perennial legume) with an average of $16.2 \%$ (Wang et al., 2014). These results suggested that $A$. sparsifolia can fix atmospheric $\mathrm{N}_{2}$, resulting in a relatively lower resorption efficiency of $\mathrm{N}$ in A. sparsifolia than in non-legume plants.

\section{Effect of Groundwater Depth on Nutrient Utilization in A. sparsifolia}

In the present study, the NUE of $\mathrm{P}$ and $\mathrm{K}$ were decreased with increasing groundwater depth, while the NUE of $\mathrm{P}$ and $\mathrm{K}$ among 2.5, 4.5, and $11.0 \mathrm{~m}$ groundwater depth had no significant differences (Tables $\mathbf{1 - 3}$ ). This result is mainly due to A. sparsifolia that adapt to the changes only by adjusting the nutrient resorption process rather than the nutrient utilization process. This result is similar to those of previous studies that the NUE of six species were similar at high and low water supply treatments in a typical agropastoral ecotone in China (Yuan et al., 2008), and the NUE of tree species depended on the species but not on nutrient availability (Aubrey et al., 2012). The NUE of $\mathrm{N}$ at $4.5 \mathrm{~m}$ groundwater depth was lower than that of 2.5 and $11.0 \mathrm{~m}$ groundwater depths because $A$. sparsifolia is a leguminous plant that can fix $\mathrm{N}$ in air, its biomass at $4.5 \mathrm{~m}$ groundwater depth is higher than that at 2.5 and $11.0 \mathrm{~m}$ groundwater depths (Zhang et al., 2018a). Future research should focus on the effects of nutrient and salinity in groundwater combined with groundwater depth on the nutrient resorption of phreatophytes. Long-term data on plant and soil in control and field experiments are also needed to measure and understand the responses of phreatophytes to groundwater drawdown combined with global change, such as variations in precipitation, temperature, and nitrogen deposition. In addition, only one phreatophyte chooses in this study, so if other phreatophytes have similar nutrient cycling strategies will need more research work in the future.

\section{CONCLUSION}

Groundwater depth significantly affected $\mathrm{P}$ and $\mathrm{K}$ concentrations in leaf, stem, and assimilating branch of A. sparsifolia, but did not influence $\mathrm{N}$ concentrations in different tissues of $A$. sparsifolia in the southern rim of the Taklimakan Desert. A. sparsifolia under different groundwater depths drastically altered the nutrient resorption parameters, such as NRP and NRE of $\mathrm{P}$ and $\mathrm{K}$, but not the nutrient uptake parameters, such as NP, MRT, and NUE. Besides, groundwater depth had significant indirect effects on the $\mathrm{P}$ and $\mathrm{K}$ resorption of $A$. sparsifolia by changing soil $\mathrm{P}$ concentration and senescent leaf $\mathrm{K}$ concentration. Hence, the variations in $\mathrm{P}$ and $\mathrm{K}$ concentrations in $A$. sparsifolia under different groundwater depths were highly associated with their resorption rather than their utilization by plants. Our results presented a new internal nutrient cycling strategy for nutrient conservation of a desert phreatophyte grown under poor soil fertility at different groundwater depths in a desert-oasis ecotone. This study may contribute to protecting and restoring phreatophytes in a hyper-arid desert ecosystem.

\section{DATA AVAILABILITY STATEMENT}

The original contributions presented in the study are included in the article/Supplementary Material, further inquiries can be directed to the corresponding author/s.

\section{AUTHOR CONTRIBUTIONS}

$\mathrm{BZ}, \mathrm{XG}$, and FZ designed the study. BZ and SZ performed the experiments and collected the data. BZ analyzed the data. BZ, GT, HY, MS, BL, XG, and FZ interpreted the data and wrote the manuscript. All authors contributed to the article and approved the submitted version. 


\section{FUNDING}

This study was supported by the Western Young Scholar Program-B of the Chinese Academy of Sciences (2018-XBQNXZB-018), the National Natural Science Foundation of China (31500367), the Program of Joint Funds of the National Natural Science Foundation of China and the Government of Xinjiang Uygur Autonomous Region of China (U1903102), the Youth Innovation Promotion Association Foundation of the Chinese Academy of Sciences (2020435), The Third Batch of Tianshan Talents Program of Xinjiang Uygur Autonomous Region (20212023) and the Project for Cultivating High-level talent of Xinjiang Institute of Ecology and Geography (E0502101).

\section{REFERENCES}

Aerts, R. (1996). Nutrient resorption from senescing leaves of perennials: are there general patterns? J. Ecology 84, 597-608. doi: 10.2307/2261481

Aerts, R., and Chapin, F. S. I. I. I. (2000). The mineral nutrition of wild plants revisited: a re-evaluation of processes and patterns. Adv. Ecol. Res. 30, 1-67. doi: 10.1016/s0065-2504(08)60016-1

Antunes, C., Chozas, S., West, J., Zunzunegui, M., Cruz, M., Barradas, D., et al. (2018). Groundwater drawdown drives ecophysiological adjustments of woody vegetation in a semi-arid coastal ecosystem. Global Change Biol. 24, 4894-4908. doi: $10.1111 /$ gcb. 14403

Arndt, S. K., Kahmen, A., Arampatsis, C., Popp, M., and Adams, M. (2004) Nitrogen fixation and metabolism by groundwater-dependent perennial plants in a hyperarid desert. Oecologia 141, 385-394. doi: 10.1007/s00442-004-1655-7

Aubrey, D. P., Coyle, D. R., and Coleman, M. D. (2012). Functional groups show distinct differences in nitrogen cycling during early stand development: implications for forest management. Plant soil 351, 219-236. doi: 10.1007/ s11104-011-0946-0

Berendse, F., and Aerts, R. (1987). Nitrogen use efficiency: a biologically meaningful definition? Funct. Ecol. 1, 293-296.

Brant, A. N., and Chen, H. Y. H. (2015). Patterns and mechanisms of nutrient resorption in plants. Crit. Rev. Plant Sci. 34, 471-486. doi: 10.1080/07352689. 2015.1078611

Drenovsky, R. E., and Richards, J. H. (2006). Low leaf $\mathrm{N}$ and $\mathrm{P}$ resorption contributes to nutrient limitation in two desert shrubs. Plant Ecol. 183, 305-314 doi: 10.1007/s11258-005-9041-z

Eckstein, R. L., and Karlsson, P. S. (2001). Variation in nitrogen-use efficiency among and within subarctic graminoids and herbs. New Phytol. 150, 641-651. doi: 10.1046/j.1469-8137.2001.00130.x

Garnier, E., and Aronson, J. (1998). "Nitrogen-use efficiency from leaf to stand level: clarifying the concept," in Inherent Variation in Plant Growth. Physiological Mechanisms and Ecological Consequences, eds H. Lambers, H. Poorter, and M. M. I. Van Vuuren (Leyden: Backhuys), 515-538.

Gui, D. W., Zeng, F. J., Liu, Z., and Zhang, B. (2013). Characteristics of the clonal propagation of Alhagi sparsifolia Shap. (Fabaceae) under different groundwater depths in Xinjiang, China. Rangeland J. 35, 355-362. doi: 10.1071/rj13004

Huang, G., Su, Y. G., Mu, X. H., and Li, Y. (2018). Foliar nutrient resorption responses of three life-form plants to water and nitrogen additions in a temperate desert. Plant Soil. 424, 479-489. doi: 10.1007/s11104-017-3551-z

Killingbeck, K. T. (1996). Nutrients in senesced leaves: keys to the search for potential resorption and resorption proficiency. Ecology 77, 1716-1727. doi: $10.2307 / 2265777$

Lefcheck, J. S. (2016). PiecewiseSEM: piecewise structural equation modeling in R for ecology, evolution, and systematics. Methods Ecol. Evol. 7, 573-579. doi: 10.1111/2041-210x.12512

Li, C. J., Zeng, F. J., Zhang, B., Liu, B., Guo, Z. C., Gao, H. H., et al. (2015). Optimal root system strategies for desert phreatophytic seedlings in the search for groundwater. J. Arid Land 7, 462-474. doi: 10.1007/s40333-015-0006-3

Li, H. F., Zeng, F. J., Gui, D. W., Zhang, L. G., Song, C., Luo, W. C., et al. (2013). Effects of cutting and burning on regeneration of Alhagi sparsifolia Shap. on the

\section{ACKNOWLEDGMENTS}

We thank Hanlin Luo, Shiming Li, Bo Wang, and Jinfeng Pang for assistance in field work at the Cele Station, and Mingfang $\mathrm{Hu}$ for assistance in soil and plant elemental analysis. We are also grateful to the referees for their reviewing of this manuscript.

\section{SUPPLEMENTARY MATERIAL}

The Supplementary Material for this article can be found online at: https://www.frontiersin.org/articles/10.3389/fpls.2021. 665168/full\#supplementary-material

southern fringe of the Taklamakan Desert, North-west China. Rangeland J. 34, 389-397. doi: 10.1071/rj12020

Liu, B., He, J. X., Zeng, F. J., Lei, J. Q., and Arndt, S. K. (2016). Life span and structure of ephemeral root modules of different functional groups from a desert system. New Phytol. 211, 103-112. doi: 10.1111/nph.13880

Liu, B., Zeng, F. J., Arndt, S. K., and He, J. X. (2013). Patterns of root architecture adaptation of a phreatophytic perennial desert plant in a hyperarid desert. S. Afr. J. Bot. 86, 56-62. doi: 10.1016/j.sajb.2013.02.003

Liu, M. (2007). Study on Groundwater Spatiotemporal Distribution Law and Its Environmental Effects in Hotan Oasis. Ph, D, Thesis. China: Xi'an University of Technology.

Lu, J. Y., Yang, M., Liu, M. G., Wang, Y. Y., and Yang, H. M. (2019). Leaf stoichiometry and resorption of $\mathrm{N}$ and $\mathrm{P}$ in lucerne at different growth stages under different water supplies. J. Plant Nutr. 42, 501-511. doi: 10.1080/ 01904167.2019 .1567776

Lü, X. T., and Han, X. G. (2010). Nutrient resorption responses to water and nitrogen amendment in semi-arid grassland of inner mongolia, china. Plant Soil 327, 481-491. doi: 10.1007/s11104-009-0078-y

Netzer, F., Schmid, C., Herschbach, C., and Rennenberg, H. (2017). Phosphorusnutrition of European beech (Fagus sylvatica L.) during annual growth depends on tree age and P-availability in the soil. Environ. Exp. Bot. 137, 194-207. doi: 10.1016/j.envexpbot.2017.02.009

Norby, R. J., and Iversen, C. M. (2006). Nitrogen uptake, distribution, turnover, and efficiency of use in a CO2-enriched sweetgum forest. Ecology 87, 5-14. doi: 10.1890/04-1950

Ren, H. Y., Kang, J., Yuan, Z. Y., Xu, Z. W., and Han, G. D. (2018). Responses of nutrient resorption to warming and nitrogen fertilization in contrasting wet and dry years in a desert grassland. Plant Soil 432, 65-73. doi: 10.1007/s11104018-3775-6

Richardson, S. J., Peltzer, D. A., Allen, R. B., and McGlone, M. S. (2005). Resorption proficiency across a chronosequence: responses among communities and within species. Ecology 86, 20-25. doi: 10.1890/04-0524

Saneoka, H., Moghaieb, R. E., Premachandra, G. S., and Fujita, K. (2004). Nitrogen nutrition and water stress effects on cell membrane stability and leaf water relations in agrostis palustris huds. Environ. Exp. Bot. 52, 131-138. doi: 10. 1016/j.envexpbot.2004.01.011

Shipley, B. (2002). Cause and Correlation in Biology: a User's Guide to Path Analysis, Structural Equations and Causal Inference. Cambridge: Cambridge University Press.

Sparks, D. L., Page, A., Helmke, P., Loeppert, R., Soltanpour, P., Tabatabai, M., et al. (1996). Methods of Soil Analysis. Part 3-Chemical Methods. Madison, WI: Soil Science Society of America Inc.

Thomas, F. M. (2014). Ecology of Phreatophytes. Progress in Botany. Berlin: Springer.

Thomas, R., Sheard, R., and Moyer, J. (1967). Comparison of conventional and automated procedures for nitrogen, phosphorus, and potassium analysis of plant material using a single digestion. Agron. J. 59, 240-243. doi: 10.2134/ agronj1967.00021962005900030010x

Vergutz, L., Manzoni, S., Porporato, A., Novais, R. F., and Jackson, R. B. (2012). Global resorption efficiencies and concentrations of carbon and nutrients 
in leaves of terrestrial plants. Ecol. Monogr. 82, 205-220. doi: 10.1890/110416.1

Vitousek, P. M. (1982). Nutrient cycling and nutrient use efficiency. Am. Nat. 119, 553-572. doi: 10.1086/283931

Wang, Z., Fan, Z., Zhao, Q., Wang, M., Ran, J., Huang, H., et al. (2018). Global data analysis shows that soil nutrient levels dominate foliar nutrient resorption efficiency in herbaceous species. Front. Plant Sci. 9:1431.

Wang, Z., Jimoh, S. O., Li, X., Ji, B., Struik, P. C., Sun, S., et al. (2020). Different responses of plant $\mathrm{N}$ and $\mathrm{P}$ resorption to overgrazing in three dominant species in a typical steppe of Inner Mongolia. China. Peer J. 8:e9915. doi: 10.7717/peerj. 9915

Wang, Z. N., Lu, J. Y., Yang, H. M., Zhang, X., Luo, C. L., and Zhao, Y. X. (2014). Resorption of nitrogen, phosphorus and potassium from leaves of lucerne stands of different ages. Plant Soil 383, 301-312. doi: 10.1007/s11104-0142166-x

Xu, S., Zhou, G. Y., Tang, X. L., Wang, W. T., Wang, G. X., Ma, K. P., et al. (2017). Diferent spatial patterns of nitrogen and phosphorus resorption efciencies in China's forests. Sci Rep-UK 7, 10584. doi: 10.1038/s41598-017-11163-7

Yasumura, Y., Hikosaka, K., Matsui, K., and Hirose, T. (2002). Leaf-level nitrogenuse efficiencyof canopy andunderstoreyspecies in a beechforest. Funct. Ecol. 16, 826-834. doi: 10.1046/j.1365-2435.2002.00691.x

Yuan, Z. Y., and Chen, H. Y. H. (2009). Global-scale patterns of nutrient resorption associated with latitude, temperature and precipitation. Global Ecol .Biogeogr. 18, 11-18. doi: 10.1111/j.1466-8238.2008.00425.x

Yuan, Z. Y., Chen, H. Y. H., and Li, L. H. (2008). Nitrogen use efficiency: does a trade-off exist between the $\mathrm{N}$ productivity and the mean residence time within species? Aust. J. Bot. 56, 272-277. doi: 10.1071/bt07139

Yuan, Z. Y., Li, L. H., Han, X. G., Chen, S. P., Wang, Z. W., Chen, Q. S., et al. (2006). Nitrogen response efficiency increased monotonically with decreasing soil resource availability: a case study from a semiarid grassland in northern China. Oecologia 148, 564-572. doi: 10.1007/s00442-006-0409-0

Yuan, Z. Y., Li, L. H., Han, X. G., Jiang, F. H., Zhao, M. X., and Lin, G. H. (2004). Effects of plant sizes on the nitrogen use strategy in an annual herb, Helianthus annuus (Sunflower). Acta Botanica Sinica 46, 889-895.

Yuan, Z. Y., Liu, W. X., Niu, S. L., and Wan, S. Q. (2007). Plant nitrogen dynamics and nitrogen-use strategies under altered nitrogen seasonality and competition. Ann Bot-LONDON 100, 821-830. doi: 10.1093/aob/mcm 178
Zeng, F. J., Bleby, T. M., Landman, P. A., Adams, M. A., and Arndt, S. K. (2006). Water and nutrient dynamics in surface roots and soils are not modified by short-term flooding of phreatophytic plants in a hyperarid desert. Plant Soil 279, 129-139. doi: 10.1007/s11104-005-0498-2

Zeng, F. J., and Liu, B. (2012). Root Ecology of Alhagi Sparsifolia. Beijing: Science Press.

Zeng, F. J., Song, C., Guo, H. F., Liu, B., Luo, W. C., Gui, D. W., et al. (2013). Responses of root growth of Alhagi sparsifolia Shap. (Fabaceae) to different simulated groundwater depths in the southern fringe of the Taklimakan Desert. China. J. Arid Land 5, 220-232. doi: 10.1007/s40333-013-0154-2

Zeng, Q. P., Brown, P. H., and Holtz, B. A. (2001). Potassium fertilization affects soil $\mathrm{k}$, leaf $\mathrm{k}$ concentration, and nut yield and quality of mature pistachio trees. Hortscience 36, 85-89. doi: 10.21273/hortsci.36.1.85

Zhang, B., Gao, X. P., Li, L., Lu, Y., Shareef, M., Huang, C. B., et al. (2018a). Groundwater depth affects phosphorus but not carbon and nitrogen concentrations of a desert phreatophyte in northwest China. Front. Plant Sci. 9:338. doi: 10.3389/fpls.2018.00338

Zhang, B., Gui, D. W., Gao, X. P., Shareef, M., Li, L., and Zeng, F. J. (2018b). Controlling soil factor in plant growth and salt tolerance of leguminous plant Alhagi sparsifolia Shap. in saline deserts, northwest China. Contemp. Probl. Ecol 11, 111-121. doi: 10.1134/s199542551801002x

Zhao, G. S., Shi, P. L., Wu, J. H., Xiong, D. P., Zong, N., and Zhang, X. Z. (2017). Foliar nutrient resorption patterns of four functional plants along a precipitation gradient on the Tibetan Changtang Plateau. Ecol. Evol. 7, 72017212. doi: $10.1002 /$ ece 3.3283

Conflict of Interest: The authors declare that the research was conducted in the absence of any commercial or financial relationships that could be construed as a potential conflict of interest.

Copyright (C) 2021 Zhang, Tang, Yin, Zhao, Shareef, Liu, Gao and Zeng. This is an open-access article distributed under the terms of the Creative Commons Attribution License (CC BY). The use, distribution or reproduction in other forums is permitted, provided the original author(s) and the copyright owner(s) are credited and that the original publication in this journal is cited, in accordance with accepted academic practice. No use, distribution or reproduction is permitted which does not comply with these terms. 